\title{
Are preventive and coping measures enough to avoid loss and damage from flooding in Udayapur district, Nepal?
}

\author{
Kenneth Bauer \\ Dartmouth College, \\ 302 Carpenter Hall, \\ Hanover, NH 03755, USA \\ E-mail: kenneth.bauer@dartmouth.edu
}

\begin{abstract}
This case study examines household vulnerability and responses in relation to flooding in Udayapur district, Nepal. It describes how communities in this region deal with flooding and asks to what extent their preventive, coping, and adaptation measures have been successful in avoiding loss and damage. A 300-household survey, along with open interviews and focus group discussions, revealed a wide range of strategies that families adopt in relation to flooding. In situ measures - such as the construction of sand embankments, stonewalls, and bamboo fences - are frequently used measures to control floods and prevent impacts. The most common coping strategies in Udayapur district are outmigration for labour and reliance on non-food income, social networks, and external support. The results show that despite high adoption rates, for a majority of the households, preventive and adaptation measures are often not enough to avoid loss and damage.
\end{abstract}

Keywords: loss and damage; prevention; coping; adaptation; climate stressors; climate change; flooding; livelihood strategies; Nepal.

Reference to this paper should be made as follows: Bauer, K. (2013) 'Are preventive and coping measures enough to avoid loss and damage from flooding in Udayapur district, Nepal?', Int. J. Global Warming, Vol. 5, No. 4, pp.433-451.

Biographical notes: Kenneth Bauer is a Lecturer at Dartmouth College, USA. His consulting work and academic research address a number of development challenges including resettlement, biodiversity conservation, and climate change. He co-founded DROKPA (http://www.drokpa.org), a non-profit organisation that partners with communities in Tibet and the Himalaya to catalyse social entrepreneurship and implement grassroots development.

\section{Introduction}

Although the world's 'least developed' countries have contributed little to global warming, they are bearing some of the heaviest impacts of anthropogenic climate change (Adger et al., 2006). Global climate change models anticipate that, among the many effects of climate change, flooding will intensify as precipitation regimes change and temperatures rise. ${ }^{1}$ While nations throughout the world will have to address this intensification of flooding, so-called 'least developed countries' (LDCs) like Nepal view 
these anticipated changes in the suddenness, frequency, and magnitude of these extreme climate events with particular alarm (IPCC, 2007).

Nepal's climate is as diverse as the country's topography, which extends from the highest mountains in the world to the rim of the Gangetic plains, almost at sea level. Nepal's varied topography makes it susceptible to climate-related disasters and the country experiences a range of natural hazards, some of which occur yearly (e.g., floods and landslides) whereas others occur less frequently (earthquakes) (UNDP, 2009a). Given its vertiginous topography and active geology - together with torrential rain during the monsoon season - Nepal experiences frequent water-related disasters including landslides, debris flows, and floods.

Between 1971 and 2007, more than 2,500 floods killed at least 3,000 people, caused more than a billion dollars' worth of damage, and damaged some 150,000 buildings. In the 1990s, one flood alone killed over 1,000 people (UNDP, 2009a). Flooding also has significant effects on Nepal's economy: a single flash flood in 1993 knocked out half of the country's electricity production for several months (NCVST, 2009). A general lack of effective response mechanisms for and strategies to deal with natural disasters exacerbates the consequences of floods. Not surprisingly, Maplecroft's index, which evaluates the vulnerability of human populations to climate-related change over the next 30 years, ranks Nepal 4th of 170 countries (CCVI, 2011). ${ }^{2}$ The choice of Nepal, then, as a site to engage with questions of vulnerability, adaptation, and residual loss and damage in relation to flooding is appropriate.

\subsection{The loss and damage framework}

The climate development knowledge network (CDKN) is concerned that current mitigation and adaptation measures are not enough to avoid the increasingly adverse effects of extreme weather events and long-term climatic changes, particularly in vulnerable communities. ${ }^{3}$ In response, CDKN is working with countries like Nepal to gain wider recognition of vulnerable populations, who are often excluded from and have limited access to the global networks that produce knowledge and enact policies to address climate change. ${ }^{4} \mathrm{CDKN}$ partners are working together to understand and plan for the societal impacts of climate change on food production, livelihood security, health, built and human capital, etc. In partnership with public, private, and non-governmental institutions, CDKN supports local and global decision-makers in designing and delivering development that is compatible with climate change by combining research, advisory services, and knowledge management.

This case study is part of multi-country research project, funded by CDKN and guided by the Institute for Environmental and Human Security of the United Nations University (UNU-EHS), to compile evidence and record stories of climate-related loss and damage in Bangladesh, Bhutan, Burkina Faso, Ethiopia, the Gambia, Kenya, Micronesia, Mozambique and Nepal. Given their respective environmental matrices and subsistence-oriented economies, these countries were identified as especially vulnerable to loss and damage from climate variability and climate change. Each case study employed the same survey template for household questionnaires, but each focused on different climatic stressors and societal impacts. Research questions were adapted for each case study according to the particular characteristics of local livelihood systems and environments [see Warner and van der Geest (forthcoming) in this issue for an overview]. 
We use the following working definition of loss and damage: negative effects from climate change and variability that people have not been able to cope with or adapt to (Warner and van der Geest, 2013, this issue). Loss and damage considers the consequence of peoples' inability to adapt to changing climate conditions. This includes the costs (economic and non-economic) and adverse effects associated with the coping and adaptation measures. Loss and damage can result from an inability to respond to climate stressors, insufficient coping and adaptation measures, the costs associated with coping and adaptation strategies, and the adverse long-term effects of adopted measures. These costs and consequences often elude quantification but cause deprivation and can impede sustainable development. The loss and damage framework recognises that the short- and medium-term effects of climate change are locked in, given the emissions we have already accumulated in our atmosphere. Loss and damage therefore attempts to account for the potential costs of future climate change, which will depend on the intensity of climatic disruptions and global mitigation efforts.

The terms 'coping' and 'adaptation' in relation to climate change are often used synonymously. This is problematic because they involve different types of responses to different types of stressors. In the CDKN loss and damage case studies, coping strategies are defined as short-term responses to the impacts of sudden events. Adaptation is defined as longer-term responses to more gradual changes (Warner and van der Geest, 2013, this issue). The adaptation measures that households adopt in response to actual and expected impacts of climate variability occur within the context of social change and demographic shifts that themselves have complex interactions.

Beyond coping and adaptation, what are the residual effects of climate variability and change - loss and damage - that people have not been able to avoid? What are the limits and costs of adaptation, particularly for vulnerable or marginal populations, to climatic change? Why do these coping and adaptation mechanisms still result in loss and damage? What happens to a household when its coping strategies are not effective enough to avoid or manage the impacts of extreme climatic events? How vulnerable are specific populations to extreme climate events and how much does climate variability affect their ability to pursue their development aspirations? These are the questions that drive this case study.

This is the context into which this case study fits. Specifically, in a set of communities located in lowland eastern Nepal, we investigated the adaptive actions undertaken - proactively or reactively - to manage the impacts of floods as well as the costs of not being able to adapt to these climate stressors. In order to address these concerns, we collected data on:

1 local perceptions of weather variability and climate patterns

2 flood impacts

3 household vulnerability to flooding in terms of livelihoods and health

4 local measures adopted to cope with and adapt to climate stressors

5 residual losses and damage in spite of these coping and adaptation measures. 
At the household and community level, we examined both the impacts of and responses to floods when they occurred (i.e., coping) and the things that local households had done to prevent and reduce the impacts of future floods (i.e., preventive strategies). Such proactive measures can also shift to long-term practices (adaptation). This study provides evidence of some of the barriers and limits that households in this part of eastern lowland Nepal face in their efforts to cope with and adapt to floods, including residual loss and damage. In doing so, it provides a context for discussing the consequences of exceeding the limits of adaptation.

\section{Methods and study site}

Fieldwork was conducted in Jogidaha and Hadiya Village Development Committees (VDCs) of Udayapur, one of Nepal's 75 districts (Figure 1, Table 1). The study site was chosen in consultation with the UNDP and other development partners, who pinpointed this region as perennially at risk of floods and vulnerable to climate change. The Government of Nepal has specifically targeted the Inner Terai, the region where Udayapur District lies, in its disaster relief and emergency preparedness planning, due to recent and sustained damages from catastrophic floods.

Figure 1 Hadiya and Jogidaha village development committees, Nepal (see online version for colours)

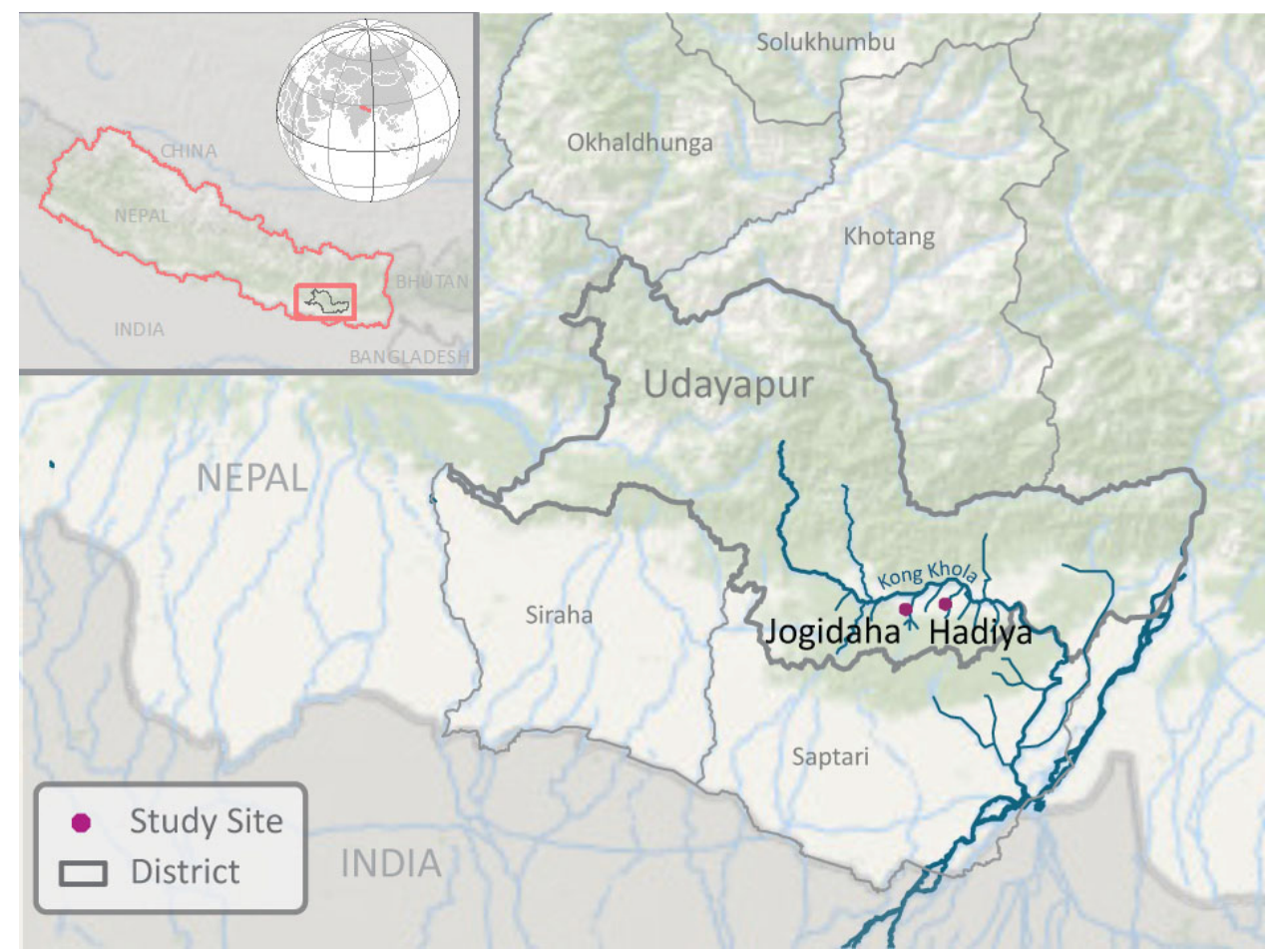


Table 1 Population of study communities

\begin{tabular}{lcccc}
\hline Population & 1981 & 1991 & 2001 & 2011 \\
\hline Udayapur district & 159,805 & 221,256 & 287,689 & 317,532 \\
Hadiya VDC & $\mathrm{n} / \mathrm{a}$ & 8,564 & 9,120 & 10,546 \\
Jogidaha VDC & $\mathrm{n} / \mathrm{a}$ & 4,698 & 5,164 & 5,876 \\
\hline
\end{tabular}

Agricultural fields in the study site are situated along the alluvial plain of Udayapur's seasonal rivers. The two main rivers in the study site, Kong Khola and Hadiya Khola, originate from the southern Siwalik range, also known as the Churia Hills. These rivers are characterised by high rates of sedimentation during the monsoon and little or no discharge during dry periods. Highly localised, prolonged rainfall can generate water volumes in excess of local drainage capacity. Between June and September, flash floods cause extensive damage even in years when overall precipitation is relatively low. When they do occur, floods can inundate agricultural soils with sand, damage paddy walls, and sometimes sweeps away fields entirely. Sometimes impacts are temporary, such as inflation in food prices and grain shortages. Other times, the costs are more lasting. In 1989, for example, a severe flood in Udayapur destroyed 25 houses and almost $70,000 \mathrm{~m}^{2}$ of fields. Floods also cause long-term damage through topsoil erosion, which reduces soil fertility and organic matter content. In turn, declining returns from land makes households less able to accumulate food reserves for the lean times when families are vulnerable to climate-related risks. ${ }^{5}$

Anthropogenic factors exacerbate seasonal flooding. Man-made obstructions such as roads, bridge piers, floating debris, weirs, barrages, and embankments restrict the flow of water, make rivers shallower, and accelerate sedimentation. We were told repeatedly by older interviewees in Udayapur that local rivers used to run in narrow channels clear and deep; today, these erstwhile rivers are shallow, trickling through sand-filled wastelands with banks that are hundreds of meters wide in places. In addition to the hydrological changes triggered by downstream development (e.g., Changu Narayan irrigation scheme), upstream land conversion and deforestation have increased sediment loads flowing into these watersheds. These erosive flows undermine the integrity of riverbanks and increase the likelihood of flash floods during monsoon.

Our research team was assembled under the auspices of IDS-Nepal, a Nepali NGO; two of the five enumerators were female, a significant factor in our ability to gain access to households and to interview women in the field. In order to elicit a wide variety of empirical data on the impacts of floods, a mixed methods qualitative approach was developed. We adopted a semi-structured survey instrument that had been developed by UNU-EHS for the case studies of the Loss and Damage in Vulnerable Countries Initiative (see Warner and van der Geest, 2013, this issue). For the Nepal study, questions were adapted as necessary to fit the cultural context (e.g., ethnicity designations) and specific climate change issue (i.e., flooding). Prior to field mobilisation, we conducted two days of training for enumerators: the household questionnaire was translated, wording was clarified, and question prompts were tweaked.

During December 2012 and January 2013, the research team completed 300 household surveys as well as four focus group discussions, numerous key informant interviews, and extensive participant observation. To randomise our sampling, we counted every fifth household and looked for the household head to interview when we entered a cluster or row of houses. The survey elicits information about demographics, 
educational attainment, agricultural production, and livelihood strategies. A series of questions asks about the specific effects of flooding in terms of loss and damage as well as the coping and adaptation measures that households have adopted. The first section of the survey records socioeconomic and demographic data and tracks sources of food and income. The next sections of the questionnaire deal with vulnerability, the ways that households cope with and adapt to floods, and the residual loss and damage associated with this climate stressor.

It is important to note that our questions about 'loss and damage' did not address these effects only in material or economic terms. There were numerous opportunities for respondents to describe non-economic impacts, particularly in the open-ended questions of the survey. Indeed, loss and damage may also be experienced in other registers, for instance, in psychological stress or social dislocation. In some of the case studies reported in this special issue, cultural losses and impacts on social cohesion and identity were prominent (e.g., Monnereau and Abraham, 2013; Traore et al., 2013; Kusters and Wangdi, 2013).

To capture changes in risk-management strategies, the questionnaire distinguishes measures that were always part of livelihood systems (preventive strategies, such as risk spreading in agriculture) and measures that were adopted in response to changing conditions (adaptation). While some of the measures that people in the study area adopted - such as construction of physical barriers to keep floodwater out of farms - are very clearly a response to climate-related stressors, other measures may be partly in response to non-climatic changes. Such adaptation measures, in the words of Moser and Ekstrom (2010, p.22026) "aim to meet more than climate change goals alone".

Aware of the need to look for the multivalent aspects of coping with and adapting to flooding, we complemented our quantitative sampling with qualitative techniques, especially focus groups and key informant interviews. As in the other CDKN case studies (this volume), open-ended interviews enabled us to record personal stories of floods. After spending several days completing questionnaires in each village of our study site, we understood a bit about the local history of flooding and could also identify key informants. We interviewed them at length to gather stories of experiences with flooding. Interviews helped us understand the subtle and often non-monetary effects of flooding experienced by householders.

In addition to personal interviews, we conducted a series of focus group discussions to gather information on the complex dynamics between climate variability and vulnerability. These focus group discussions enriched the quantitative data we had collected through surveys. In particular, talking with groups helped us understand flooding impacts and responses at the community level. The focus group discussions also allowed us to explore differences in the experiences of men and women, young and old, castes and different occupational groups (e.g., crop cultivators, labourers, traders) as well as between wealth groups.

\subsection{Demographics, livelihoods, and the state of development in Udayapur}

The communities in which we worked are quite diverse in terms of their cultural and linguistic composition. ${ }^{6}$ Our household questionnaire elicited ethnicity by asking questions about mother tongue, religion, and the categories used in Nepal's 2010 National Census (GoN, 2010) (Table 2). The ethnic composition of the Inner Terai has been profoundly influenced by large-scale migrations of hill groups (e.g., Rai, Tamang, 
Magar) that began after 1960, when DDT was broadly applied to eliminate mosquitoes carrying malaria. Across the southern girth of Nepal, what were once impenetrable malaria-infested forests - to which only the indigenous Tharu groups had adapted - were cleared for agriculture and new settlements. In the span of a few generations, hundreds of thousands of migrants settled in lowland districts like Udayapur (Kansakar, 1974; Nagendra et al., 2005).

Table 2 Ethnic composition of study communities

\begin{tabular}{lc}
\hline Ethnicity & $\%$ \\
\hline Chaudhari (Tharu) & 37.0 \\
Chhetri & 26.7 \\
Rai, Tamang, Magar & 15.3 \\
Dalit (Pariyar, Biswakarma, Sada) & 11.3 \\
Brahmin & 7.0 \\
Other & 2.7 \\
\hline
\end{tabular}

There are latent political and economic issues among ethnic groups as a consequence of these 20th century migrations, particularly in relation to land use change and the distribution of natural resources. One elder Tharu man put it like this, "Before, when we were the only ones who lived here because we could resist malaria. But when they cleared the mosquitoes, we could not resist the migrants swarming in from all over the country!" Coping with climate-related risks sometimes requires collective action to effectively mobilise communal labour and to leverage support from outside organisations. Given the political tensions latent to land use issues, organising collective efforts to respond to flooding may be challenging in communities that are ethnically diverse and socially striated as in our study site. If there is a lack of solidarity within the community - and the diversity of ethnicities in our study site suggests this might be the case - the potential for communal and reciprocal labour arrangements is highly attenuated.

Most of Nepal's inhabitants live in rural areas and small-scale, subsistence agriculture is the mainstay of the economy, employing nearly $80 \%$ of the country's workforce (World Bank, 2010). Indeed, agriculture constitutes the core economic activity in our study site: nearly every household $(86 \%)$ described their primary occupation as 'farming' and almost everyone (91\%) in this population owns some agricultural land. Four-fifths $(83 \%)$ of these households cultivate all or some of their crops on their own land. Those without adequate land holdings farm on community land $(16 \%)$, sharecrop $(12 \%)$, or rent land (3\%). Land typically has mixed uses, i.e., fields, house, fruit trees, animal shelters, wood and hay storage, etc. Overall, very little private land (1\%) is left fallow or used for purposes other than farming (7\%)in the VDCs of Hadiya and Jogidaha. There is a relatively low intensification of agricultural production among households in the study site: only a third (35\%) of available agricultural land is irrigated. ${ }^{7}$ Means of cultivation are still mostly rudimentary: three-quarters use draught animals for plowing, with just $12 \%$ owning tractors; the remainder must rent plow animals or mechanised traction.

According to local informants, agricultural productivity is in decline. More than four in five households reported that crop production has decreased, either by 'a lot' (48\%) or 'a little' (33\%). Gaps in food security also emerge in our data. Almost half (47\%) of the study population stated that they experience months in which they 'eat less' while more 
than half (58\%) of households in our study site purchase at least half or more of the food they consume; regardless of income or amount of land owned, four out of five households $(80 \%)$ in this population buy at least some of the food they consume (Table 3).

Table 3 Amount of crop production sold by households

\begin{tabular}{lcc}
\hline Amount sold & $\%$ & \# households \\
\hline Everything & 0.7 & 2 \\
Almost everything & 0.4 & 1 \\
More than half & 1.8 & 5 \\
Approximately half & 1.5 & 4 \\
Less than half & 5.5 & 15 \\
Hardly anything & 8.1 & 22 \\
Nothing & 82.0 & 222 \\
Total & 100 & 271 \\
\hline
\end{tabular}

Even with the little they have to sell, local farmers have difficulty accessing markets and commodifying their agricultural production, particularly during flooding events. Cross tabulation of our data showed that, of those who self-identified (i.e., perceived themselves) as having 'less income', almost all (96\%) sell none of their crop production. By contrast, almost a quarter (24\%) of those who report having 'more income' sell half or more of their crop production. More than half of all families (59\%) sell 'nothing' from their crop production. The data we collected indicate a lack of subsistence capital, built assets, and savings among study site households, which may constrain their ability to reconstruct following disasters as well as curtail the range of livelihood options they can avail to cope with and adapt to evolving climate hazards.

Households do not, of course, rely on crop production alone to subsist. Almost every family ( $92 \%$ ) owns some kind of productive domestic animal (Table 4). Three-quarters of the families $(76 \%)$ we interviewed own a shed, which indicates the value of animals in the domestic production cycle and the relative investment in their wellbeing. These sheds also commonly double as hay and wood stockpiling areas as well as equipment storage areas. For households in this part of Nepal, goats are an essential source of protein along with domesticated pigeons, the most common fowl kept. Domestic animals also serve critical ritual functions in these communities, particularly around important festivals like Dasain, when animals are ritually sacrificed in honour of the goddess Kali. In addition, livestock are important to households as liquid capital and insurance in times of crises and also act as powerful symbols of wealth and property (e.g., bride's wealth).

Table 4 Animal ownership

\begin{tabular}{lc}
\hline Animal type & \% households \\
\hline Goats and sheep & 71 \\
Cattle & 64 \\
Fowl & 64 \\
Oxen & 58 \\
Pig & 20 \\
\hline
\end{tabular}


These days, few locals (11\%) choose to fish, which suggests that the opportunity costs do not justify allocating time and labour to this mode of production. Where fishing is a viable source of food or for sale, one would expect to see equipment - nets, traps, rope in active use. Instead, during our house visits in Jogidaha and Hadiya, we noted how few households had fishing gear. Two plausible explanations come to mind. Across the Terai, the ethnic group most closely identified with fishing - the Tharu - has declined as a proportion of the population. Still, the Tharu comprise more than a third $(37 \%)$ of the population in the study site, so fishing could still plausibly be commonly practiced. Another explanation is that of environmental change in these watersheds - particularly the silt that has accumulated upstream of the Chandra Nahar irrigation scheme over the past 70 years. Shifting riverbanks, declining channel depths, obstructions, and other habitat changes have resulted from this siltation and likely led to declines in fish populations.

Beyond household assets, there are many ways to assess the local state of development in our study site. Water is a good place to start. The source of drinking water for the vast majority of households $(88 \%)$ is a simple hand pump, with some $(10 \%)$ using wells. Fewer than half of the families surveyed (44\%) had a toilet. The notable absence of sanitation infrastructure is, in part, explained by a cultural preference among the Tharu to keep polluting influences outside the home; some respondents also claimed that with frequent flooding, latrines are destroyed, diminishing their usefulness and, sometimes, worsening sanitary conditions. There are many climate-related public health concerns that relate to sanitation and waterborne diseases. ${ }^{8}$ Diarrheal diseases are already a significant problem in Nepal, and flooding can increase surface water pollution. The problems associated with poor quality water are compounded by Nepal's general lack of health facilities, widespread poverty, and gaps in hygiene awareness, among other issues. Recent evidence from Nepal shows increased incidence of climate-dependent diseases such as cholera and diarrhoea. ${ }^{9}$

Just as with the rudimentary state of physical infrastructure seen in the villages of Jogidaha and Hadiya, investments in education were found to be lacking. The heads of household whom we interviewed self-reported a low level of educational attainment, with more than two-thirds $(69 \%)$ having never gone to school or having only basic literacy; only one out five (21\%) had a secondary education. Literacy levels among women in this population are even lower: among the 69 female household heads in our sample only six $(8.7 \%)$ had received primary or secondary education. ${ }^{10}$ Investment in education could help Nepal's rural residents cope with and adapt to climate-related disasters by expanding the range of livelihood options available to Nepal's rural citizens. As it is, a little more than half $(58 \%)$ of the households we interviewed in Udayapur district had members who earn non-farm income, primarily through physical wage labour and secondarily through petty trade and salaried occupations like teaching or government administration. Of the $58 \%$ of households who reported non-farm income, very few (13\%) earn wages from salaried (white-collar) positions, a function of the generally low education status of study site residents and the lack of such positions in the district.

Based on our data, there is clearly an active local market for farm labour, likely attributable to the large numbers of productive labourers who have migrated regionally and abroad. More than half (55\%) of the households in our study site employ individuals from outside families to work in their fields. Conversely, half of households $(50 \%)$ reported that at least one member works on someone else's farm. Our data indirectly point to wealth disparities as a predictor of participation in the local labour market: there 
are clear differences in patterns of agricultural employment based on household income, with only a quarter $(28 \%)$ of those who reported having 'more income' labouring on others' farms.

Remittance is central to Nepal's contemporary economy. While Nepalese have long migrated outside of the nation's borders to earn money, the Maoist civil war (1996-2006) accelerated and intensified out-migration - by 2010, an estimated 4 million Nepalese were working in foreign countries according to Nepal's national census (GoN, 2010). Our study site is no exception to these trends. The pastoral landscapes of Udayapur district might at first seem less affected by broader flows of labour and money. In fact, these farming villages are deeply imbricated in these regional and global economic networks.

More than a third of our respondents (35\%) reported receiving remittances from members working outside the village; most of the remittance funds flowing into these communities come from individuals labouring abroad (83\%). In our study communities, three times as many labourers go abroad compared with those who work within the district or other regions of Nepal (Kathmandu, Butwal, etc.). Malaysia is the most popular destination (40\%) for those going abroad, followed by Qatar (22\%), India (12\%), Saudi Arabia (12\%) and a variety of other Middle Eastern states. However, going abroad and accessing such employment relies on having enough start-up capital to secure (through middlemen) the requisite visas, work permits, air tickets, and jobs, etc.; this is an increasingly expensive proposal for families across Nepal.

Given this baseline information on demographics, livelihood strategies, and the state of local development in the Udayapur study site, it is possible now to discuss the impacts of floods in the area and describe the types of preventive, coping, and adaptation strategies being used by local people to deal with floods. The last part of the results section focuses on residual losses and damages.

\section{Results}

A key challenge in evaluating the current and future impacts of climate variability is to downscale global data and to infer from broad scale models what may occur in a handful of villages in eastern Nepal. ${ }^{11}$ Since flooding is the focus of this study, the immediately relevant climate indicator for which we have data is rainfall. Data availability is limited for Udayapur district, like much of Nepal: there is only one meteorological station in the whole district. ${ }^{12}$ From this single source, we compiled data on inter-annual and intra-annual variability. The period covered by our survey appears to have had below average totals in terms of annual precipitation according to the district's meteorological records (Figure 2). In accordance with that, a majority (61\%) of households reported that the frequency of floods has decreased in the past 20 years. On the other hand, nearly everyone $(96 \%)$ reported having experienced flood events and two-thirds asserted that floods have become more severe. These findings underscore the importance of the differences between frequency and severity in considering the kinds of impacts that extreme weather events have. 
Figure 2 Annual rain, Udayapur district, Nepal (1956-2010)

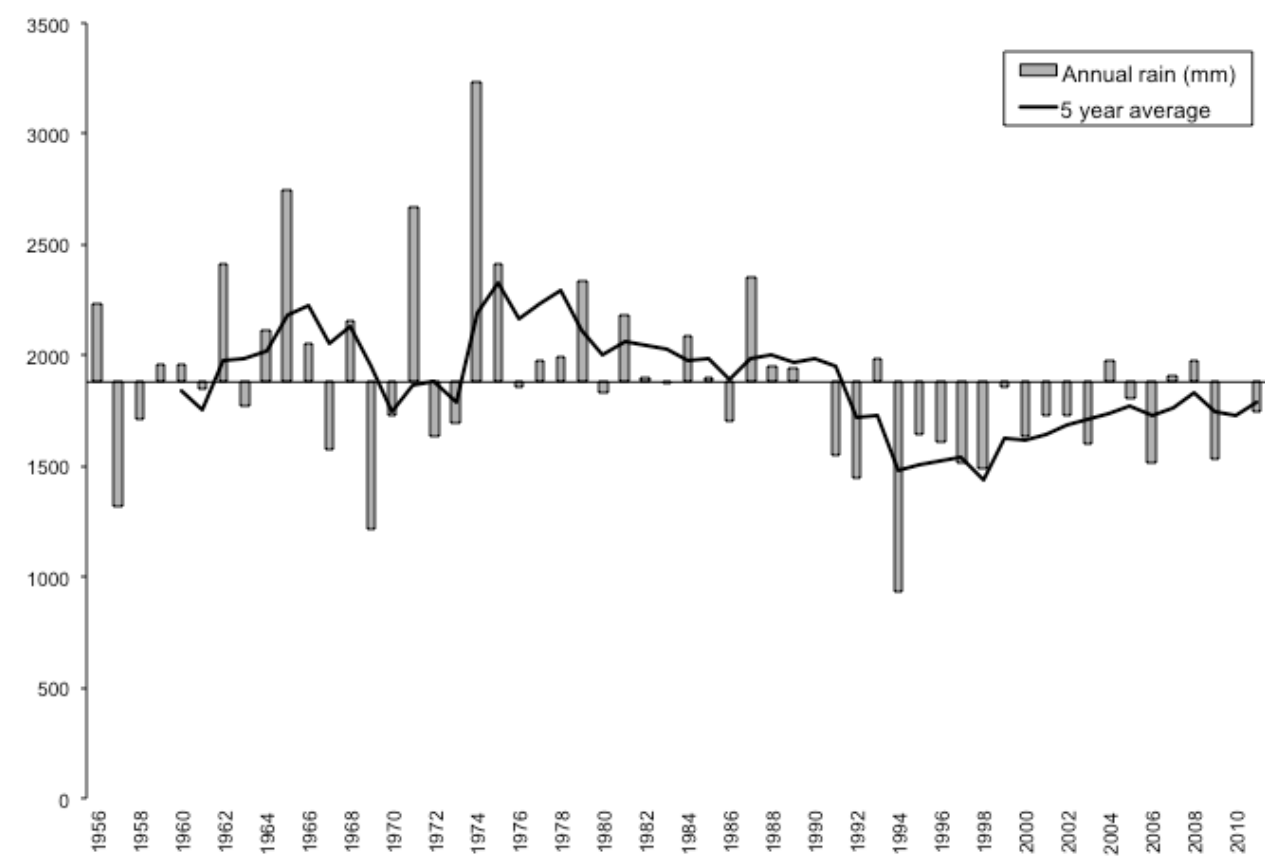

\subsection{Prevention and adaptation}

In the questionnaire, we asked respondents to focus on a particular flood event - typically the most severe, or the most recent - and to answer questions on impact, responses, and residual loss and damage for that event specifically. The flood years people decided to focus on were very diverse, with 1995-1996 and 2008-2011 mentioned most frequently. Respondents were asked whether they had adopted any preventive measures to reduce impacts before the specific flood to which their answers referred. Without probing for specific preventive measures, about a third $(35 \%)$ of our respondents indicated that their households had indeed undertaken some kind of action to prevent the recurrent impacts of floods. Most commonly, they had constructed sand or stonewalls, gabions, bamboo fences or they had planted trees along the river. Many also mentioned contributing labour or other resources to community-based or government/NGO-initiated flood-control measures. In addition to the group of respondents who indicated that they had adopted preventive measures before the flood year they focused on, another 35\% adopted such measures afterwards in anticipation of new flood events.

After these open questions about preventive measures, we inquired about some specific measures, including changes to houses, construction of physical barriers, agricultural changes, livelihood diversification and migration. These measures largely involve adaptations that aim to reduce vulnerability to flooding. Again, more than two thirds $(71.3 \%)$ indicated that they had adopted at least one such measure. One in four $(25.3 \%)$ of those who took preventive measures had made changes to their houses like relocating to safer locations and using alternative building materials. Likewise, more than half $(56.3 \%)$ had built physical barriers around their homes and fields in order to reduce 
damage. The other measures were less commonly adopted. Though labour migration is common, and many households have non-farm income, only $15.4 \%$ and $20.1 \%$ respectively indicated that they engage in these activities to reduce vulnerability to flooding (Table 5).

Table 5 Measures adopted by households to prevent flood impacts

\begin{tabular}{lcc}
\hline Measure & $\%\left(n=293^{*}\right)$ & \# households \\
\hline None & 28.7 & 84 \\
Changes to house & 25.3 & 74 \\
Physical barriers & 56.3 & 165 \\
Agricultural change & 6.8 & 20 \\
Shift to non-farm income & 20.1 & 59 \\
Migration & 15.4 & 45 \\
\hline
\end{tabular}

Note: *Seven respondents did not answer the questions about preventive measures.

In our study sites, adaptation to flooding to a large extent is rooted in preventive measures. Farmers invest substantial time and resources into maintaining community flood control works including tree planting, gabion wall and bamboo weir construction, and embankment maintenance as well as volunteer labour (e.g., hauling rocks and materials) for larger-scale engineering projects funded by the government. Communities use traditional bioengineering methods and materials (e.g., bamboo fences and sand dykes) to diminish the worst effects of flooding. District- and village-level government offices have funded the construction of stone and cement retainer walls to stabilise soils in flood-prone areas. However, these infrastructural and engineering works are very limited; government efforts remain inconsistent and underfunded.

Eventually, adaptation to climate change may entail switching to crop varieties better suited to projected conditions; for the present, it seems, farmers in Udayapur are retaining their traditional practices. It is worth considering whether changes in precipitation regimes and flood cycles are prompting local farmers in Udayapur to shift their planting choices or other agricultural practices. There is little indication of a shift away from rice as the major crop grown here in contrast to reportage from the Kathmandu Valley (Shaikh and Sughra, 2013). When asked whether they had, "made any changes in agricultural production to prevent impacts of flood in the future", the overwhelming majority of households (93\%) answered 'no' (Table 5).

Out of 293 households that experienced flood events, only 49 families (16.7\%) have not adopted any preventive measures - no direct, proactive actions - to reduce their vulnerability to floods. For some, flood prevention works were not a priority because of their household's structural poverty. These desperately poor families simply have other, more immediate contingencies to address like finding wage labour and scrounging a meal. Another factor associated with preventive actions is available labour. Outmigration (particularly to Malaysia, the Middle East, and India) has produced shortages of young men, who would traditionally contribute labour to community projects. Communal initiatives to control floods, for example to repair embankments and construction weirs, have been neglected because of other demands on households' productive labour. Another subset takes little action because their properties are outside of flooding zones or they are not dependent on agricultural production for their subsistence or income. 


\subsection{Impacts from flooding}

Impacts from flooding occur despite preventive measures. In the aftermath of a flood, households typically face a short-term crisis. In our study site, $73 \%$ of the households interviewed reported adverse effects of flooding on their household economy. The most commonly cited impact of flooding was on crop production: almost half (46\%) of our interviewees reported 'severe' effects of flooding on their crops, with others (14\%) noting 'moderate' effects. Almost half (44\%) noted higher food prices in the aftermath of floods (Table 6).

Table 6 Flood-affected households by impact type $(\mathrm{n}=300)$

\begin{tabular}{lccccc}
\hline Impact on & $\begin{array}{c}\text { Moderate } \\
\text { impact }\end{array}$ & $\begin{array}{c}\text { Severe } \\
\text { impact }\end{array}$ & $\begin{array}{c}\text { Total } \\
\text { affected }\end{array}$ & $\begin{array}{c}\% \text { of } \\
\text { households }\end{array}$ & $\begin{array}{c}\text { \% of affected } \\
\text { households }\end{array}$ \\
\hline Crops & 43 & 137 & 180 & 60.0 & 84.9 \\
Food prices & 89 & 43 & 132 & 44.0 & 62.3 \\
House/properties & 18 & 55 & 73 & 24.3 & 34.4 \\
Trees & 23 & 6 & 29 & 9.7 & 13.7 \\
Livestock & 11 & 6 & 17 & 5.7 & 8.0 \\
Fishing & 5 & 3 & 8 & 2.7 & 3.8 \\
Trade & 8 & 0 & 8 & 2.7 & 3.8 \\
\hline
\end{tabular}

A quarter of sampled households noted 'severe' (19\%) or 'moderate' $(6 \%)$ effects from flooding on family homes. That more homes are not damaged may be a function of house placement (typically not directly adjacent to rivers) and the relatively higher location of buildings in comparison to fields, which are mostly located within the floodplain of local watersheds.

With respect to flooding, domestic animals seem to have good survival rates as only a small number of households reported 'moderate' (4\%) or 'severe' $(2 \%)$ effects on livestock from flood events; most reported 'no negative' effects on their livestock as a result of flooding. Still, grazing areas and trails used by animals may be inundated or damaged by flooding. Further, overgrazing and out-of-season grazing problems may worsen when grazing lands are made inaccessible due to flooding. Depending on the type and size of kept domestic animals can impacts on streambeds through trampling, grazing, browsing, etc. Local grazing rules differ, with important implications for livestock impacts on watershed management: Hadiya VDC does not allow community members to graze animals along riverbeds but this is permitted in Jogidaha VDC. In order to cope with flooding impacts such as these, households in this study site adopt a variety of measures.

\subsection{Coping measures}

In response to property damage including to houses, fields, and crops, households employ a number of strategies to cope with flooding impacts. Among other strategies, they may: look for alternative sources of food, sell livestock or other household assets to buy food, earn non-farm income, call upon social networks, rely on external assistance in the event of a flood, or some combination of these. About two thirds $(67 \%)$ of households interviewed had adopted at least one such coping strategy (Table 7). 
Table 7 Coping measures adopted by households

\begin{tabular}{lccc}
\hline Coping measure & $\begin{array}{c}\text { Adopting } \\
\text { households }\end{array}$ & $\begin{array}{c}\text { \% of all households } \\
(300)\end{array}$ & $\begin{array}{c}\text { \% of adopting } \\
\text { households (201) }\end{array}$ \\
\hline Help from organisations & 124 & 41.3 & 61.7 \\
Help from others & 91 & 30.3 & 45.3 \\
Extra income & 91 & 30.3 & 45.3 \\
Sale of properties & 66 & 22.0 & 32.8 \\
Migration & 50 & 16.7 & 24.9 \\
\hline
\end{tabular}

Shortfalls in crop production are supplemented locally by harvesting from fruit trees, collecting in the forest, and fishing. Fruits, especially papayas and mangos, are an important nutritional supplement for households. Three in four families (74\%) own fruit trees, though only 11 reported having stands with enough trees $(>50)$ to produce fruit for sale. $^{13}$

Another way to cope with climate-related risks is to migrate outside for labour in search of wages to compensate for actual or potential shortfalls in household income (Banerjee et al., 2011). Nearly one in five households (17\%) said they had responded to floods by sending household members outside to earn extra income engaging in crafts like carpentry and construction, basket making, tailoring, and petty trade (Table 7). In addition to long-distance migration - today to destinations like Malaysia, Saudi Arabia, and Kathmandu, among others - a third (31\%) of our study population looked for extra income locally in order to buy food (Table 7) to cope with shortfalls in household income that may result from floods (e.g., through loss of agricultural land, labour time, etc.).

These employment-seeking patterns can be seen both as a form of adaptation and a coping mechanism. There is adaptation in the search for outside sources of income to spread the long-term risks associated with increasingly intense or frequent floods. But wage labour is also a coping mechanism, triggered in aftermath of a given flood, when people must seek off-farm income to offset immediate losses and earn cash to rebuild their lives. Migration is clearly an important economic strategy for households in our sample. But the links between labouring off-farm and coping with and adapting to flooding risks are not always clear. Some families use labour migration specifically to prevent risks from future floods. But flooding is typically one of a suite of reasons for migrating. Among other factors, land fragmentation, growing population, declining returns from agricultural land, and diminishing per capita land holdings precipitate labour migration from this part of Nepal.

Regardless of whether migration is used for preventive or coping purposes, the consequences of labour migration are gendered. In particular, the outmigration of productive household members results in more work at home for women (c.f. Mehta, 1996). Outmigration increases the workload of those who stay behind, especially women who must assume both agricultural and domestic workloads, the benefits of remittances notwithstanding. Coupled with the long-term outmigration of men for labour, climate-related disasters such as floods place great demands on marginally self-sufficient communities, which may contribute to the disruption of local security safety nets and the breakdown of family support structures (Nellemann et al., 2011).

Yet another way to cope with climate-related risks is to seek outside assistance. Asked if they had ever received government or NGO support to cope with the impacts of floods, $42.3 \%$ of households in our Udayapur study site said they had (Table 7). In the 
absence of government relief, social entrepreneurs have sometimes played a critical role in helping communities cope with flood impacts. For instance, one local community leader, whose own father had drowned, donated his family's land for a disaster shelter that was constructed for Jogidaha VDC residents with government and NGO funds.

In our study site, almost a quarter $(23 \%)$ of the households interviewed had sold property including homes, livestock, and heirloom possessions in response to flooding. Additionally, close to $40 \%$ of interviewed households had reduced expenses (e.g., school fees, health care, productive investments, etc.) and food consumption in the aftermath of floods. Arguably, these measures could be coping behaviours. But they are also a sign that existing coping measures are failing. Indeed, more than three-quarters $(78 \%)$ of households reported that the coping strategies they had carried out to deal with flood impacts were 'not enough'.

\subsection{Loss and damage}

Residual negative impacts from flooding result if existing coping and adaptation responses to flooding are insufficient and the associated costs cannot be recouped. In some situations, response measures may have short-term benefits but there are negative effects in the long-term. In Udayapur, nearly every family lives and farms within eyeshot of a riverbank so year after year they rebuild the walls of their fields before and after floods while they try to rehabilitate damaged paddy soils.

Even though they had rebuilt walls and constructed barriers, moved their homes, and adopted new building materials along with other costly efforts in terms of labour and time lost, a majority of respondents reported that the coping measures they had taken to respond to flooding were not enough. Fully half of the households we interviewed noted that, despite the preventive measures they had taken, they had still experienced 'severe negative effects' from flood events. Indeed, households made many sacrifices to cope with flooding impacts.

Resignation, expressed in the Nepali idiom of ke garne ('what to do'), permeated our interviewees accounts of the loss and damage they had experienced because of flooding. "Now I can only cultivate 3 bigha even though I own 23 bigha according to the documents. Kong Khola is flowing over all my other lands. I can't even recognise the border of my land these days", said one farmer of the losses he could not recoup. There were several registers of resignation: some described efforts to control flooding that had simply been swept away, while others spoke to a sense of helplessness before the forces of nature. Thus, one woman said, "The river is already so wide. How can we control it?" Resignation, too, was understandable in local attitudes towards given the 'help' afforded by the government. Though local government officials claimed that $40-50 \%$ of VDC budgets were spent every year on flood control, visible evidence to validate these claims was largely absent.

By a two to one margin, our respondents noted that the effects of flooding were more severe for women and children than for men. Women and children are more at risk of drowning and have difficulty moving about during floods, especially if they are sick. Pregnant women face great obstacles accessing ambulances and other government health services. School is frequently cancelled or is difficult to reach during flood events; women and children may also have to spend more time collecting water, fodder, and fuel wood. 


\section{Discussion}

There are no universally accepted or objective means of measuring 'vulnerability'. As such, a comprehensive assessment of the causes and conditions that lead to household vulnerability in relation to flooding is beyond the scope of this research. Since 'vulnerability' remains a contested term (Sietz et al., 2012) in development literature, the emphasis here is on the elements that constrain the ability of households to cope with and mitigate climate-related risks. Drawing upon Warner and van der Geest's (forthcoming) framework, we can note that there are a number of pathways by which vulnerable households incur loss and damage from flooding.

Structural characteristics such as gender, income, education, ethnicity, among others, all affect a household's vulnerability in relation to flooding. During our interactions with villagers in Udayapur, local narratives about flooding converged on a number of variables that forecast a household's capacity to cope with and adapt to flooding: whether or not members had migrated outside for labour, amount of farm land owned, level of intensification, and support from government projects and international relief efforts. Households that succeed in coping with flooding have diversified income sources; are able to maintain strong social networks; and can access to government support programmes. Of concern, however, are the more numerous households that are vulnerable - they are not adapting successfully and they have few viable opportunities to diversify their livelihoods. Why are such households more or less vulnerable to flooding and its attendant impacts?

There are many reasons why a given family may be unable to cope with climate stressors. Among our household sample were truly destitute families: landless, low caste, and utterly marginalised. When they can, they labour for day wages. Mostly, they go hungry and live out their lives at the edge of vulnerability. After one or successive natural disasters, poor families with insufficient financial, land, or other assets are likely to lose the minimal buffer they have and face spiralling indebtedness and poverty. Such vulnerable populations are systematically disadvantaged in terms of accessing resources, which exposes them to increased risks during disasters and in the wake of climate-related events. These risks include physical dislocation and psychological trauma, the loss of household resources (e.g., livestock, built capital such as paddy walls and structures), and catastrophic harvest failure, among others.

In other cases, families go through temporal cycles in which their resilience as a household is less robust. For instance, when illness or death strike a household, the family's savings or subsistence capital can be wiped out; there are also better times when everyone is healthy and productive, when the family has enough members who can labour and earn wages. In other words, both structural conditions (termed 'structural vulnerability' in the climate risk literature) and singular situations (i.e., 'proximate vulnerability') interact in complex ways and shape a household's response to life's contingencies, including flooding (van der Geest and Dietz, 2004).

The regional complexities and politics of resource use and watershed management must also be acknowledged here. At all levels, people with whom we spoke in our study sites identified the Chandra Nahar irrigation scheme (in neighbouring Saptari district) as a key driver of changes they had observed over generations in the hydrology of local watersheds. The dilemmas associated with this downstream development underscore the challenges associated with coordinating and aligning policies related to climate. The more densely populated districts of Terai, which are supplied with waters from this 
irrigation scheme, have relatively more political capital than Udayapur. So any proposal to open the irrigation scheme's sluices to flush river channels and clear sediment upstream, for example, would be met by loud opposition from communities downstream that rely on this same water for irrigation. This reinforces the notion that solutions at the local level will be insufficient to solve the problem of sedimentation originating from waterworks downstream.

As we have seen, climate stressors clearly affect now and will continue to impact future food security and livelihood strategies as well as public health and education. In this flood-prone region of Nepal, extreme climate events cause severe and sometimes lengthy disruptions to schooling, commerce, and public services. What kind of coping mechanisms and adaptations will future generations in Udayapur district devise to deal with climate variability and extreme weather events? This research has highlighted a number of indigenous strategies, everyday practices, and creative innovations that communities already use to respond to the anticipated or realised impacts of floods. In this, we are reminded that the solutions to climate change and adaptation processes go far beyond technological innovations and market mechanisms. But development in Udayapur will be compromised if efforts - local, regional, and national - to mediate the impacts of a changing climate are insufficient or not timely.

\section{References}

Adger, W.N., Paavola, J. and Hug, S. (2006) Fairness in Adaptation to Climate Change, Massachusetts Institute of Technology, Cambridge.

Banerjee, S., Gerlitz, J.Y. and Hoermann, B. (2011) Labour Migration as a Response Strategy to Water Hazards in the Hindu Kush-Himalayas, ICIMOD, Kathmandu.

Climate Change Vulnerability Index (CCVI) (2011) [online] http://maplecroft.com/about/news/ ccvi.html (accessed 8 October 2013).

Government of Nepal (GoN) (2010) Nepal Census 2010, Central Bureau of Statistics, Kathmandu.

Intergovernmental Panel on Climate Change (IPCC) (2007) Climate Change Vulnerability and Adaptation: Nepal Water Resources, Prepared as part of the US Country Studies Program, Washington, DC, IPCC 4th Assessment Report and UNDP Climate Profiles.

Kansakar, V. (1974) Population Change in Nepal: A Study of Mobility during 1911-1961, PhD thesis, Department of Geography, Patna University.

Kusters, K. and Wangdi, N. (2013) 'The costs of adaptation: changes in water availability and farmers' responses in Punakha district', Bhutan. Int. J. Global Warming, this issue.

Mehta, M. (1996) 'Our lives are no different from that of our buffaloes'. Agricultural change and gendered spaces in a central Himalayan valley', in Rocheleau, D., Thomas-Slayter, B. and Wangari, Es. (Eds.): Feminist Political Ecology: Global Issues and Local Experiences, pp.155-179, Routledge, London.

Monnereau, I. and Abraham, S. (2013) 'Limits to autonomous adaptation in response to coastal erosion in Kosrae, Micronesia', Int. J Global Warming, this issue.

Moser, S.C. and Ekstrom, J.A. (2010) 'A framework to diagnose barriers to climate change adaptation', PNAS, Vol. 107, No. 51, pp.22026-22031.

Nagendra, H., Karmacharya, M. and Karna, B. (2005) 'Evaluating forest management in Nepal: views across space and time', Ecology and Society, Vol. 10, No. 1, p.24.

Nellemann, C., Verma, R. and Hislop, L. (Eds.) (2011) Women at the Frontline of Climate Change: Gender Risks and Hopes. A Rapid Response Assessment, United Nations Environment Programme, GRID-Arendal. 
Nepal Climate Vulnerability Study Team (NCVST) (2009) Vulnerability Through the Eyes of the Vulnerable: Climate Change Induced Uncertainties and Nepal's Development Predicaments, Institute for Social and Environmental Transition-Nepal (ISET-N, Kathmandu) and Institute for Social and Environmental Transition (ISET, Boulder, Colorado) for Nepal Climate Vulnerability Study Team (NCVST), Kathmandu.

Practical Action Nepal (2009) Temporal and Spatial Variability of Climate Change over Nepal (1976-2005), Practical Action Nepal, Kathmandu, Nepal.

Shaikh, S. and Sughra, T. (2013) Nepali Farmers Abandon Rice as Monsoon Shifts, 19 February, Reuters AlertNet [online] http://www.trust.org/alertnet/news/nepali-farmers-abandon-rice-asmonsoon-shifts (accessed 8 October 2013).

Sietz, D., Choque, S. and Ludeke, M. (2012) 'Typical patterns of smallholder vulnerability to weather extremes with regard to food security in the Peruvian Altiplano', Reg. Environmental Change, Vol. 12, No. 3, pp.489-505.

Traore, S., Owiyo, T. and Sokona, Y. (2013) 'Dirty drought causing loss and damage in Northern Burkina Faso', Int. J. Global Warming, this issue.

United Nations Development Program (UNDP) (2009a) National Strategy for Disaster Risk Management, Government of Nepal Ministry of Home Affairs, Kathmandu.

United Nations Development Program (UNDP) (2009b) Nepal Human Development Report 2009, State Transformation and Human Development, Government of Nepal Ministry of Home Affairs, Kathmandu.

van der Geest, K. and Dietz, T. (2004) 'A literature survey about risk and vulnerability in drylands, with a focus on the Sahel', in Dietz, A.J. et al. (Eds.): The Impact of Climate Change on Drylands: With a Focus on West-Africa, pp.117-146, Kluwer Academic Publishers, Netherlands.

Warner, K. and van der Geest, K. (forthcoming) 'Loss and damage from climate change: local-level evidence from nine vulnerable countries', International Journal of Global Warming.

World Bank (2010) Nepal Annual Report, Nepal, Kathmandu.

World Bank (2011) Climate Risk and Adaptation Country Profile - Nepal, Global Facility for Disaster Reduction and Relief [online] http://sdwebx.worldbank.org/climateportal/ index.cfm?page $=$ country_historical_climate\&ThisRegion $=$ Asia\&ThisCCode $=$ NPL $\quad$ accessed 8 October 2013).

\section{Notes}

1 Mean annual temperatures are projected to increase between $1.3-3.8^{\circ} \mathrm{C}$ by the $2060 \mathrm{~s}$ and $1.8-5.8^{\circ} \mathrm{C}$ by the $2090 \mathrm{~s}$, and this warming is expected to occur more rapidly during the dry months (December-May). Winters are projected to be drier and monsoon summers wetter, with some sources estimating a threefold increase in monsoon rainfall.

2 The Climate Change Vulnerability Index (CCVI, 2011) combines the risk of exposure to climate change and related extreme events (drought, cyclones, landslides, flooding and sealevel rise), with the degree of current sensitivity to that exposure and the ability of the country to adjust to, or take advantage of existing or anticipated stresses resulting from climate change.

3 CDKN is funded by the UK Department for International Development (DfID) through 2015, with additional funding from the Dutch Ministry of Foreign Affairs.

4 This research on Loss and Damage in Nepal was conducted with the financial assistance of United Nations University and the technical leadership of the CDKN.

5 Some estimates suggest a loss of $1.7 \mathrm{~mm}$ of productive soil annually in Nepal, reducing already scarce productive agricultural land (Practical Action Nepal, 2009). 
6 'Ethnicity' is a complex and very much still evolving concept in Nepal that encompasses Sanskritic norms of caste, diverse religious modalities from animism to Buddhism and Hinduism (along with syncretic blends of these belief systems), place- and clan-based identities, and laws which have differentiated and defined the peoples of this diverse nation. The Muluki Ain, promulgated in 1854, officially ranked the peoples of Nepal along caste and ethnic lines.

7 Percent of land irrigated $=$ (total land irrigated $/$ total area of farm cultivated $) * 100$. $\left(460,870 \mathrm{~m}^{2} / 1,309,440 \mathrm{~m}^{2}\right) * 100=35.2 \%$.

8 In addition to its human toll, poor water quality can also increase the incidence of liver diseases in domestic animals.

9 The presence of dengue has significant ties to a changing climate. In 2006, dengue (Aedes aegypti) - previously unrecorded in Nepal - was reported in major urban areas of the Terai. In 2009, dengue was observed in Katmandu. Recent evidence also indicates an elevation migration of the Anopheles fluviatilis - the vector for malaria - above elevations of $1,500 \mathrm{~m}$, and the number of endemic malaria districts across Nepal has increased from 13 to 52 in recent years (World Bank, 2011).

10 In Nepal, girls have less access to formal education: only $18 \%$ of women have at least secondary education compared to $40 \%$ of men (UNDP, 2009b). Nationally, literacy rates show marked gender differences: $81 \%$ for men and 55\% for women (UNDP, 2009b); for our study population, literacy rates among both men and women were even lower than national averages.

11 In addition to the government's data resources, climate databases relevant to Nepal include the World Bank Climate Change Knowledge Portal (http://sdwebx.worldbank.org), Global Historical Climatology Network (GHCN), the UN Food and Agriculture Organisation (FAO), the World Meteorological Organisation, the International Center for Tropical Agriculture (CIAT), and R-HYdronet as well as a number of additional databases in Australia, New Zealand, the European Union, and the International Centre for Integrated Mountain Development (ICIMOD), among others.

12 Average annual rainfall is $1,900 \mathrm{~mm}$ in Nepal. However, these statistics vary by region and altitude. Rainfall in Nepal is driven by the monsoons, which migrate through a majority of the country between June and September; winters are largely dry.

13 Another crop about which we did not ask directly is cannabis, the cultivation of which is common in our study sites, especially among Tharu families, who typically have one to several plants growing within their compounds. While it is illegal to cultivate cannabis for sale in Nepal, several informants discreetly told us that cannabis sells for NRs. 3,000 per kilogram to middlemen who distribute the product to Udayapur district headquarters, Gaighat, as well as urban centres like Kathmandu. In the interest of protecting our interlocutors, we did not collect systematic data on this source of income, but given its ubiquity, this crop is surely an important part of the local economic picture. 